Article

\title{
Electrospun Anion-Conducting Ionomer Fibers-Effect of Humidity on Final Properties
}

\author{
Manar Halabi ${ }^{1}$, Meirav Mann-Lahav ${ }^{1}$, Vadim Beilin ${ }^{1}$, Gennady E. Shter ${ }^{1}$, Oren Elishav ${ }^{1,2}$, \\ Gideon S. Grader 1,2,*iD and Dario R. Dekel 1,2,*iD \\ 1 The Wolfson Department of Chemical Engineering, Technion-Israel Institute of Technology, \\ Haifa 3200003, Israel; manarh@campus.technion.ac.il (M.H.); meiravml@technion.ac.il (M.M.-L.); \\ vadimbe@technion.ac.il (V.B.); shter@technion.ac.il (G.E.S.); orene@campus.technion.ac.il (O.E.) \\ 2 The Nancy \& Stephan Grand Technion Energy Program (GTEP), Technion, Israel Institute of Technology, \\ Haifa 3200003, Israel \\ * Correspondence: grader@technion.ac.il (G.S.G.); dario@technion.ac.il (D.R.D.)
}

Received: 3 April 2020; Accepted: 27 April 2020; Published: 1 May 2020

check for updates

\begin{abstract}
Anion-conducting ionomer-based nanofibers mats are prepared by electrospinning (ES) technique. Depending on the relative humidity $(\mathrm{RH})$ during the ES process $\left(\mathrm{RH}_{\mathrm{ES}}\right)$, ionomer nanofibers with different morphologies are obtained. The effect of relative humidity on the ionomer nanofibers morphology, ionic conductivity, and water uptake (WU) is studied. A branching effect in the ES fibers found to occur mostly at $\mathrm{RH}_{\mathrm{ES}}<30 \%$ is discussed. The anion conductivity and WU of the ionomer electrospun mats prepared at the lowest $\mathrm{RH}_{\mathrm{ES}}$ are found to be higher than in those prepared at higher $\mathrm{RH}_{\mathrm{ES}}$. This effect can be ascribed to the large diameter of the ionomer fibers, which have a higher WU. Understanding the effect of RH during the ES process on ionomer-based fibers' properties is critical for the preparation of electrospun fiber mats for specific applications, such as electrochemical devices.
\end{abstract}

Keywords: electrospinning; fibrous morphology; relative humidity; polymer fibers; ionomer

\section{Introduction}

Electrospinning (ES) is broadly applied to generate nanofibers from a wide range of materials, including polymers, metals, ceramics, and composites [1-5]. This technique [6-10] allows control of the fibers' morphology and diameter, which play important roles in their final applications. Solution properties such as precursor concentration, polymer molecular weight, viscosity, solvent characteristics as well as process conditions greatly affect the electrospun fibers [7,8,11-14]. Such nanofibers have potential applications in the biomedical $[15,16]$, energy $[17,18]$, and other fields. The electrospinning process often involves usage of organic solvents, which are toxic, expensive, and considered environmentally unfriendly. This motivated the researchers to develop the "green process", which is a more eco-friendly ES process that uses aqueous polymer solutions [19,20]. In addition, the high viscosities of the polymer solutions require using low polymer concentrations, thereby limiting the utilization of the ES process due to the large amounts of organic solvents needed. The "green process" overcomes these limitations, allowing higher polymer concentrations in water for more effective and productive ES procedure [21].

The influence of environmental conditions during electrospinning on the morphology of polymer fibers has been investigated [11,22,23]. For example, the relative humidity during ES, $\mathrm{RH}_{\mathrm{ES}}$, plays a critical role for the formation of "porous morphology" [24]. Casper et al. [12] studied the effect of increasing $\mathrm{RH}_{\mathrm{ES}}$ and varying polystyrene (PS) molecular weight (MW) on the pore size distribution of the electrospun fibers. They found that raising the $\mathrm{RH}_{\mathrm{ES}}$ increases the number of pores and their diameter. Higher MW leads to larger pores on the fibers' surface. The effect of changing $\mathrm{RH}_{\mathrm{ES}}$ and 
solvents ratios on the surface morphology of electrospun PS fibers was reported elsewhere $[25,26]$. A study demonstrated the effects of solution's viscosity and $\mathrm{RH}_{\mathrm{ES}}$ on fibers' morphology and claimed that monitoring these two parameters facilitated fibers' architecture control, which changed from beaded fibers to smooth uniform fibers [23]. In addition to examining the external morphology, Pai et al. [27] presented porous structures within electrospun PS fibers while electrospinning at $\mathrm{RH}_{\mathrm{ES}}$ in the $24-43 \%$ range. Based on TEM analysis, the void fraction of electrospun PS in DMF was about $30 \%$. It was shown that the internal pores have a significant effect on the mechanical, optical, as well as electrical properties of the fibers.

Although electrospinning of (inert) polymers has been extensively reported, this process was scarcely studied for the case of ionic polymers, usually called ionomers [28-37]. While some protonconducting ionomers have been the base of first attempts to produce electrospun proton-conducting fiber mats [38-43], only a few studies can be found on electrospun anion-conducting fiber mats [17,44,45].

In this work, we investigate the electrospinning process of an anion-conducting ionomeric material. We specifically focus on an interesting branching phenomenon that is observed in anion-conducting fibers that were electrospun under $30 \% \mathrm{RH}_{\mathrm{ES}}$. According to a study by Yarin et al. [46], branching occurs when the static undulations of a cylindrical jet become unstable at the sites of the highest local curvature, where secondary jet branches are ejected from the primary jet. This phenomenon was also explained by Tan [47]. The branching effect had been demonstrated on polymer fibers [48] and piezoelectric fibers [49]; however, all the studies mentioned above were done using nonconducting polymers. The branching effect can be leveraged to drastically increase the surface area of fiber products; nevertheless, it is unclear what governs this effect in conducting polymers and whether they are as sensitive to the environmental conditions during the electrospinning process as nonconductive polymers. Moreover, due to the ionic character of the anion-conducting ionomers, it is especially interesting to investigate the effect of the ES process on their final properties.

The goal of this article is to investigate the effect of $\mathrm{RH}_{\mathrm{ES}}$ on the electrospun anion-conducting polymer nanofibers' morphology as well as fibers' mat properties. The effect of $\mathrm{RH}_{\mathrm{ES}}$ on the branching of anion-conducting polymer is presented and a qualitative model explaining this effect is suggested. Understanding the relationship between $\mathrm{RH}_{\mathrm{ES}}$ and the structure, $\mathrm{WU}$, and anion conductivity of the electrospun ionomer nanofibers would enable us to achieve fiber mats with tailored and improved properties for their numerous applications in electrochemical devices. Such fiber mats can be used, for instance, in advanced anion exchange membrane fuel cells (AEMFCs) [50-54] as a catalyst bed as well as a membrane.

\section{Experimental}

Anion-conducting ionomeric material (FAA-3 in its $\mathrm{Br}^{-}$form) was purchased from Fumatech BWT GmbH, Germany. FAA-3 is a quaternary ammonium functionalized aromatic PPO (Poly (p-phenylene oxide))-based polymer. The solvent used for preparing the ES precursor solutions was $\mathrm{N}, \mathrm{N}$-dimethylformamide (DMF) (Bio-Lab ltd., Jerusalem, Israel). Precursor solutions were prepared by dissolving the anion-conducting ionomer in DMF with ionomer concentration of $30 \mathrm{wt} \%$. The solutions were magnetically stirred for $2 \mathrm{~h}$ at room temperature until complete dissolution of the ionomer.

The ionomer solutions were electrospun in an electrospinning machine-NS24, (Inovenso, Istanbul, Turkey), in an environmentally controlled chamber. Precursors were loaded into a 5-mL syringe and fed to the ES system at a flow rate of $0.3 \mathrm{~mL} \mathrm{~h}^{-1}$ for $6 \mathrm{~h}$. The tip to collector distance was $14.5 \mathrm{~cm}$. A positive charge of $20 \mathrm{kV}$ was applied on the needle, and a negative charge of $3 \mathrm{kV}$ was applied to a flat collector. The flat collector size is $130 \mathrm{~mm}$ by $370 \mathrm{~mm}$, it moved back and forth $60 \mathrm{~mm}$ along the long axis at a speed of $10 \mathrm{~mm} \mathrm{~s}^{-1}$ to ensure fiber deposition homogeneity. The chamber's temperature was set constant at $24-25^{\circ} \mathrm{C}$, and the $\mathrm{RH}_{\mathrm{ES}}$ was varied in the range of $20 \%-50 \%$.

The obtained ionomeric mats were dried in a vacuum oven at $40{ }^{\circ} \mathrm{C}$ for $16 \mathrm{~h}$ to remove the residual solvent. The morphology of the nanofibers was characterized by high-resolution scanning electron microscopy (HR-SEM, Ultra Plus, Zeiss, Switzerland) at a magnification range of $\times 1000-10,000$. 
The diameter of the electrospun fibers was obtained by HR-SEM images analysis of three different areas on ionomer mats deposited on carbon conductive tape. The fibers' diameter distribution was calculated by a statistical analysis of at least 30 data points from each sample.

The WU of the electrospun ionomer samples was measured using a VTI SA + instrument (TA Instruments, New Castle, DE, USA), using protocols detailed elsewhere [55-58]. In brief, each electrospun ionomer sample was dried in situ for a maximum of $60 \mathrm{~min}$ at $50{ }^{\circ} \mathrm{C}$ and $\mathrm{RH}$ close to $0 \%$. After that, the temperature was set constant at $40{ }^{\circ} \mathrm{C}$ and the $\mathrm{RH}$ was then raised from $10 \%$ to $90 \%$ in intervals of $20 \%$. Each RH step was maintained until the sample weight reached equilibrium (WU changes smaller than $0.001 \mathrm{wt} \%$ in $5 \mathrm{~min}$ ). The temperature during the WU measurements was kept at $40{ }^{\circ} \mathrm{C}$. Values of WU were calculated using Equation (1) [55,59], where the "wet" and "dry" weight $\left(W_{(w e t)}\right.$ and $W_{(d r y)}$, respectively) were measured at the end of each equilibrium step and at the end of the initial drying step, respectively:

$$
W U=\frac{W(w e t)-W(d r y)}{W(d r y)} \times 100 \%
$$

The WU kinetics were also determined, by measuring the mass change of the ionomer mat electrospun sample as a function of time at every RH step. The characteristic time constant, $\tau$, was calculated by fitting the experimental data with the following equation $[55,60]$ :

$$
\frac{W_{t}-W_{0}}{W_{\infty}-W_{0}}=\frac{M_{t}}{M_{\infty}} \cong 1-\exp \left(-\frac{t}{\tau}\right)
$$

where $W_{t}$ is the mass of sample at time $t, W_{0}$ is the mass at the beginning of the RH step, $W_{\infty}$ is the mass of membrane at equilibrium state, $M_{t}$ is the mass gain at time $t$, and $M_{\infty}$ is the mass gain of the ionomer mat at equilibrium.

Bromide anion conductivity measurements were conducted on the ionomer mats electrospun at different RHs. These measurements were made in a conductivity chamber of an MTS-740 ionic conductometer (Scribner Inc., Southern Pines, NC, USA) using the protocol detailed elsewhere [58]. The bromide anion conductivity was calculated using the ionomer mat resistance measured with a 4-point probe cell in a sealed, thermally insulated chamber under continuous $\mathrm{N}_{2}$ gas conditioned to the desired humidity. The ionomer mat samples were first equilibrated at $40{ }^{\circ} \mathrm{C}$ at $90 \% \mathrm{RH}$ for $1 \mathrm{~h}$, the $\mathrm{RH}$ was then decreased from $90 \%$ to $10 \%$ in intervals of $20 \%$, then back from $10 \%$ to $90 \%$, following the procedure reported elsewhere [61]. Resistance values were measured perpendicular to the fiber mat, in the through-plane (TP) direction. The TP resistance, R, was measured by impedance spectroscopy using PSM1735 Frequency Response Analyzer (Newtons4th Ltd., Leicester, UK). The TP conductivity was then calculated as $[61,62]$

$$
\sigma_{T P}=\frac{d}{A \cdot R}
$$

where $d$ is the mat thickness, $A$ is the cross-sectional area through which the current passes $\left(0.5 \mathrm{~cm}^{2}\right)$, and $R$ is the measured resistance.

The velocity of the jet was calculated using the model reported by Ding et al. [63]. This model is based on the mass conversation of the polymer in the fiber. While the jet is elongated under different ES parameters and times, the volume of polymer along the fiber length must equal the volume of polymer that was consumed. Therefore, the model considers the diameter of the jet. The velocity is calculated by

$$
v_{1}=\frac{Q_{s}}{S_{1} \cdot t^{\prime}}
$$

where $Q_{s}$ stands for the consumption of spinning solution $(\mathrm{mL}), S_{1}$ is the cross-sectional area of the fiber $\left(\mu \mathrm{m}^{2}\right)$, and $t$ is the electrospinning time (h). 


\section{Results and Discussion}

\subsection{Ionomer Fibers Morphology}

The ionomer fibers electrospun at $\mathrm{RH}_{\mathrm{ES}}=20 \%$ were mostly flat belts. This can be rationalized by the formation of an early skin on the fibers due to fast evaporation at $\mathrm{RH}_{\mathrm{ES}}=20 \%$. The skin prevents uniform fiber shrinkage and eventually collapses into a belt (Figure 1a). A similar effect has been observed and modeled in our work on other fiber materials [64,65]. At $\mathrm{RH}_{\mathrm{ES}}=30 \%$, a more significant branching effect was observed (Figure $1 \mathrm{~b}$ ); while at $\mathrm{RH}_{\mathrm{ES}}=40 \%$ and $50 \%$, the fibers were smooth and cylindrical (Figure 1c,d) without any visible branching. This observation of the electrospun ionomer branching effect is further confirmed by measuring the fiber diameter distribution (Figure 2).
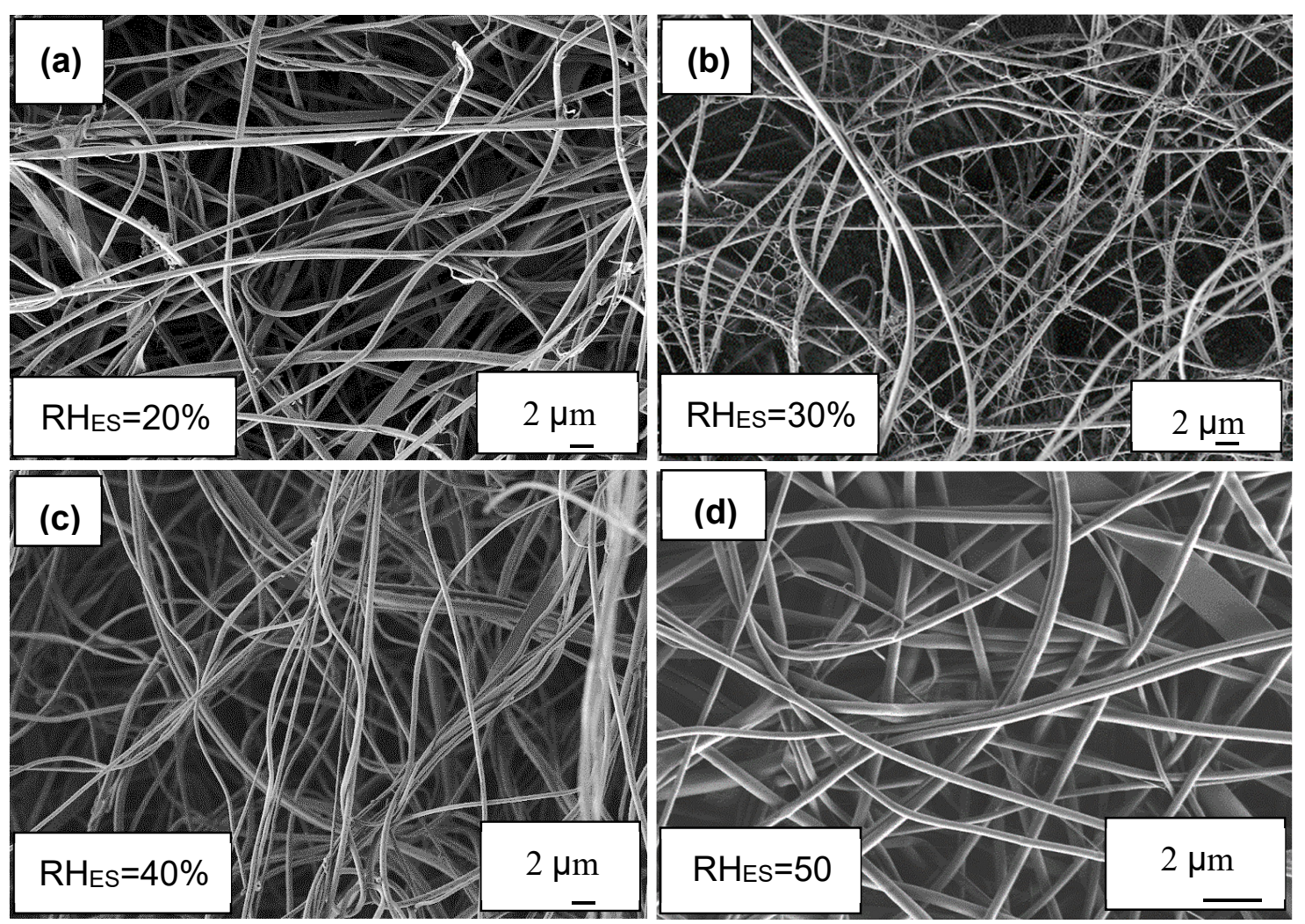

Figure 1. SEM images of ionomer fibers electrospun at $\mathrm{RH}_{\mathrm{ES}}$ range of $20 \%-50 \%$. All SEM images taken at $\times 5000$ magnification. (a) $20 \% \mathrm{RH}_{\mathrm{ES}}$, (b) $30 \% \mathrm{RH}_{\mathrm{ES}}$, (c) $40 \% \mathrm{RH}_{\mathrm{ES}}$ and (d) $50 \% \mathrm{RH}_{\mathrm{ES}}$.

The diameter distributions at $\mathrm{RH}_{\mathrm{ES}}=20 \%, 40 \%$, and $50 \%$ are monomodal (Figure 2a,c, d), whereas at $\mathrm{RH}_{\mathrm{ES}}=30 \%$, a bimodal diameter distribution can clearly be seen in Figure $2 \mathrm{~b}$. The diameter of the branches (small fibers) is in the $80-180 \mathrm{~nm}$ range.

As $\mathrm{RH}_{\mathrm{ES}}$ increased from $20 \%$ to $30 \%-50 \%$, the main average fiber diameter decreased from $\sim 600 \mathrm{~nm}$ to a constant value of $\sim 400 \mathrm{~nm}$ (see Figure 3). The larger width of the fibers electrospun at $\mathrm{RH}_{\mathrm{ES}}=20 \%$ may be due to their flat morphology, where the original cylindrical fiber collapsed into a belt, thus spreading over a larger width. The bimodal diameter distribution at $30 \% \mathrm{RH}_{\mathrm{ES}}$ can be explained by the branching mechanism, due to excess charge in unstable areas on the primary cylindrical jet $[48,49]$. Although some small ionomer fibers are also observed during $\mathrm{ES}$ at $\mathrm{RH}_{\mathrm{ES}}=20 \%$, the diameter distribution of the electrospun ionomer fibers is not bimodal. 

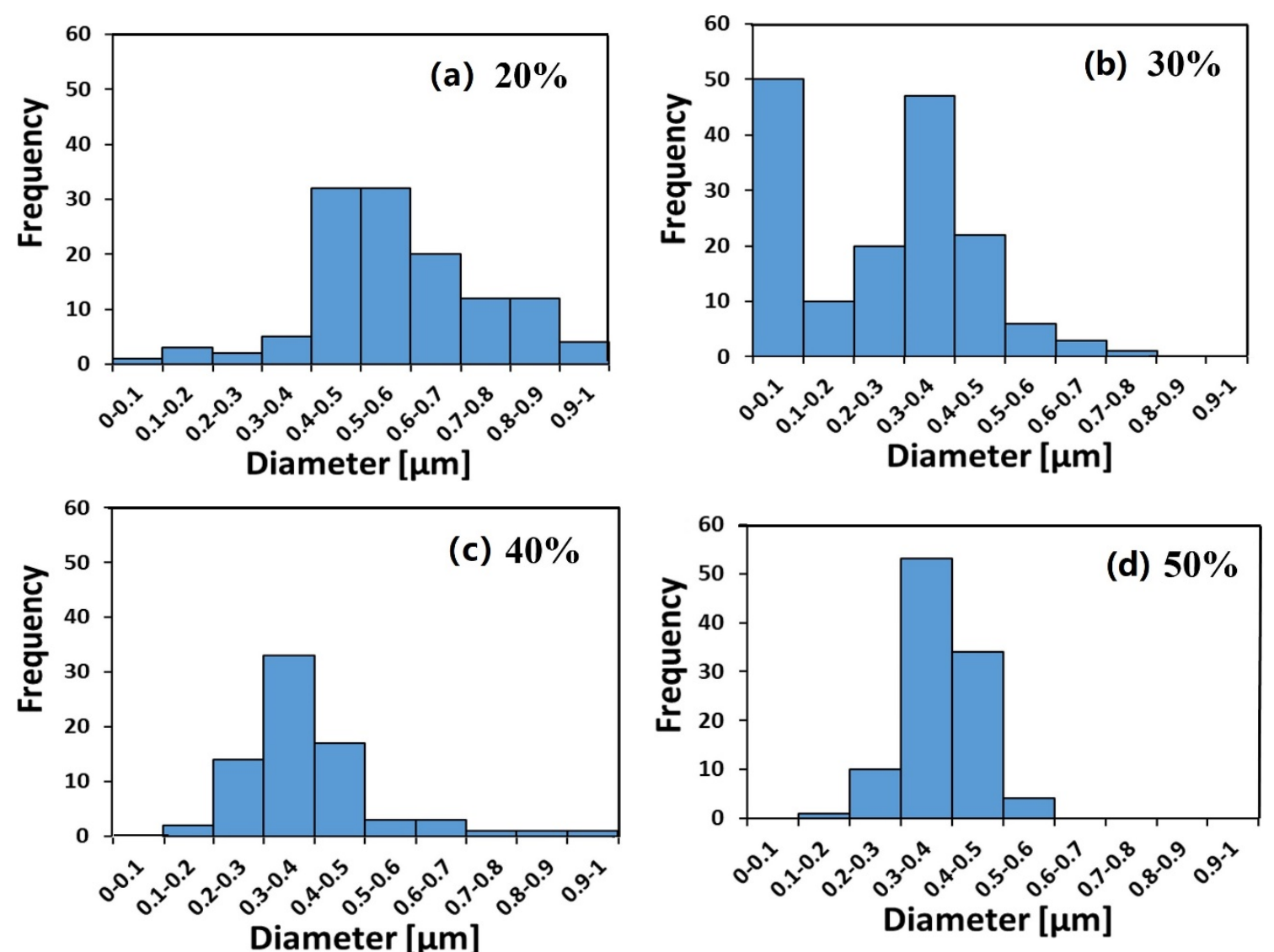

Figure 2. Fibers' diameter distribution of ionomer fibers electrospun under a relative humidity $\left(\mathrm{RH}_{\mathrm{ES}}\right)$ range of $20 \%-50 \%$. (a) $20 \% \mathrm{RH}_{\mathrm{ES}}$, (b) $30 \% \mathrm{RH}_{\mathrm{ES}}$, (c) $40 \% \mathrm{RH}_{\mathrm{ES}}$ and (d) $50 \% \mathrm{RH}_{\mathrm{ES}}$.

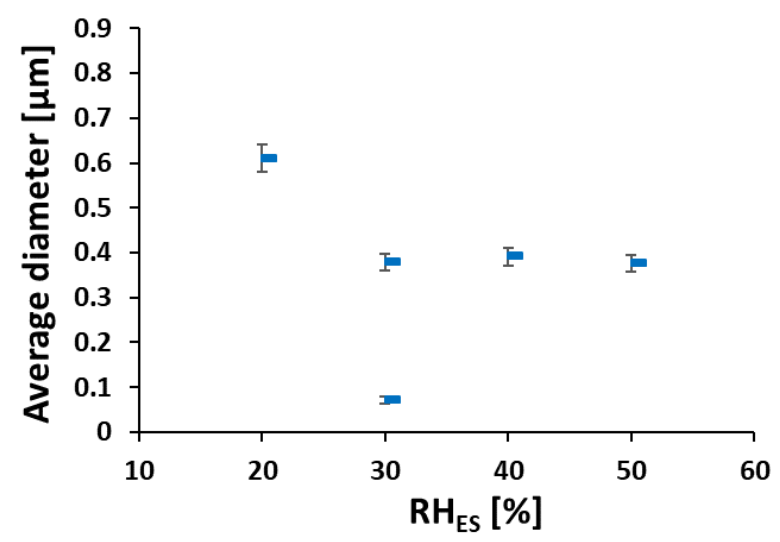

Figure 3. Fibers' average diameter vs. $\mathrm{RH}_{\mathrm{ES}}$ (calculated from data in Figure 2).

Depending on the hydrophobic or hydrophilic nature of the polymer [66], the RH can either increase or decrease the nanofibers' diameter. When hydrophilic polymers such as polyvinylpyrrolidone and polyethylene oxide are electrospun at higher $\mathrm{RH}$, the polymers solutions solidify more slowly due to slower evaporation rate [67]. This gives rise to a smaller diameter due to further stretching of the fiber. Another effect that plays a role here is that at a higher $\mathrm{RH}$, the electric charges on the fibers' surface can discharge to the surrounding water vapor more easily. Thus, the charge on the fiber is reduced, hence the attraction to the collector and stretching force are reduced, which in turn leads to larger fiber diameters [26]. In the present case, ES at low $\mathrm{RH}_{\mathrm{ES}}(20 \%)$ caused fast evaporation of DMF, giving rise mostly to flat fibers with an average width of $600 \mathrm{~nm}$. Above $\mathrm{RH}_{\mathrm{ES}}=20 \%$, fast evaporation of the solvent is prevented, more stretching occurs, and the cylindrical cross-section is 
maintained. At $40 \%$ and $50 \% \mathrm{RH}_{\mathrm{ES}}$, the discharging effect becomes more dominant, thus we do not see an additional decrease in fibers' diameter below $400 \mathrm{~nm}$ as shown in Figure 4.

(a)

$20 \% \mathrm{RE}_{\mathrm{ES}}$

Fast evaporation \& solidification

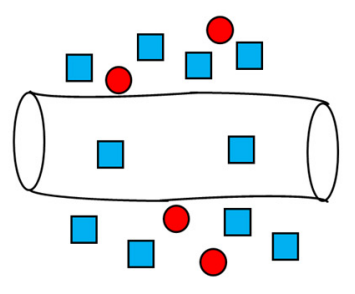

Water (b)

$30 \% \mathrm{RE}_{\mathrm{ES}}$

Maximum branching effect

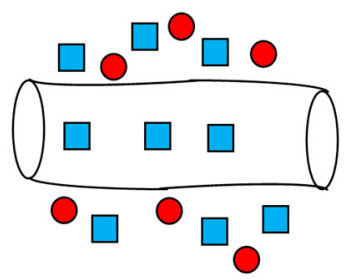

(c)

$40-50 \% \mathrm{RE}_{\mathrm{ES}}$

Fast discharge

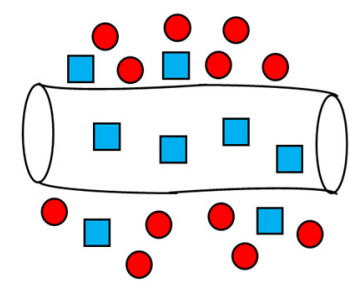

Figure 4. Scheme of electrospun fibers during their flight towards the collector at different $\mathrm{RH}_{\mathrm{ES}}$ : (a) $20 \%$, (b) $30 \%$, and (c) $40-50 \%$.

The two trends described above, involving solvent evaporation and discharging, occur simultaneously and have opposing effects. The maximal branching phenomena at $30 \% \mathrm{RH}_{\mathrm{ES}}$ has not been observed before. It is not clear why branching is subdued at lower RH and eliminated at higher RH. Baumgarten et al. [68] investigated the effect of surrounding gas during ES on fibers' morphology. Electrospinning in Freon atmosphere gave rise to a branching effect. However, ES in air at identical conditions (15 kV and $75 \mathrm{TCD}$ ) did not show any branching. This difference was attributed to the higher breakdown voltage of Freon compared to air. We believe that the lower breakdown voltage of the humid atmosphere during ES at high $\mathrm{RH}_{\mathrm{ES}}(40-50 \%)$ causes a discharge of the electric charges on the fibers' surface to the surrounding water vapor. This effect reduces the surface charge concentration at the unstable points; thus, branching does not occur.

\subsection{Water Uptake}

It can be seen (Figure 5a) that the WU increases with RH for all the ionomer mat samples. Over the whole range of $\mathrm{RH}$ values, the ionomer mat sample prepared at $\mathrm{RH}_{\mathrm{ES}}=20 \%$ has higher WU compared with those electrospun at higher $\mathrm{RH}_{\mathrm{ES}}$. The ionomer mat samples prepared at $\mathrm{RH}_{\mathrm{ES}}=30 \%$ and $40 \%$ have almost the same WU, even though the sample prepared at $\mathrm{RH}_{\mathrm{ES}}=30 \%$ has a bimodal fiber distribution. The reason for this is that the weight fraction of the small diameter segment in the bimodal sample is $1 / 16$ of the larger diameter segment. (The average diameter of the fibers in the bimodal sample are 50 and $400 \mathrm{~nm}$, while the ratio of small vs. large ionomer fibers per unit area is 4). Hence, water absorption on the small fibers does not contribute significantly to the overall WU. 

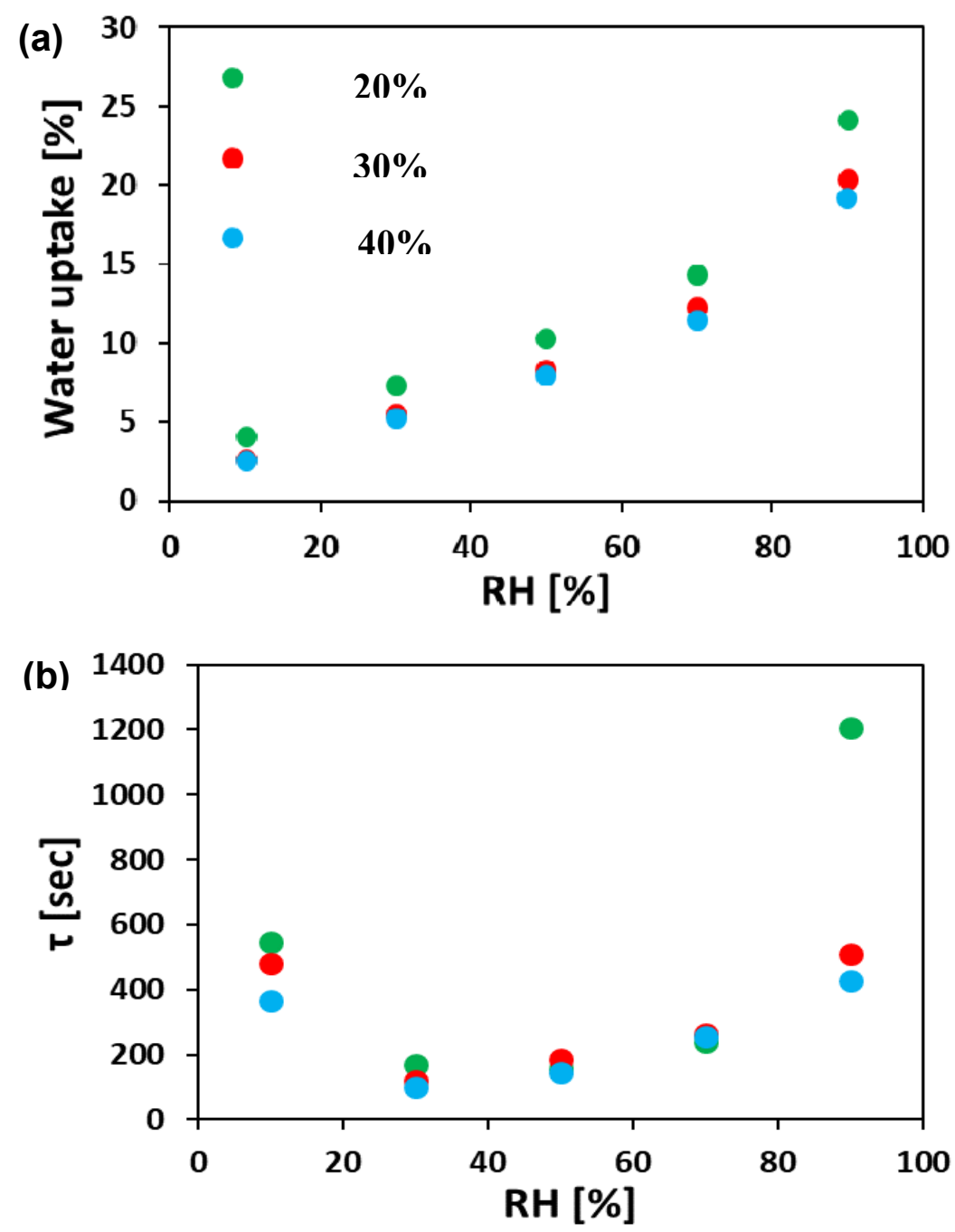

Figure 5. (a) Water vapor absorption isotherms and (b) characteristic time constant, $\tau$, for electrospun ionomer mats. All tests were done at $40{ }^{\circ} \mathrm{C}$. $\mathrm{RH}-$ relative humidity.

The characteristic time constant, $\tau$, was calculated from Equation (2), as described in the experimental section. Figure $5 \mathrm{~b}$ summarizes the resulting $\tau$ for all samples. The electrospun ionomer mats had a relatively large $\tau$ at $10 \% \mathrm{RH}(350-550 \mathrm{~s})$. As RH is increased, $\tau$ decreases to a minimum at RH (30-50\%) and then increases ( $\tau=400-1200 \mathrm{~s})$ at higher $\mathrm{RH}$. The minimal value of $\tau$ in the $30 \%-50 \%$ range of RH indicates that the fastest WU kinetics in these materials occurs in the mid-RH region. This is consistent with the trends found for WU studies of different nonporous anion-conducting membranes [55,64].

The high value of $\tau$ at low $\mathrm{RH}$ can be rationalized by the presence of smaller water content in the gas phase, thus resulting in a lower flux of water molecules towards the surface. The faster WU kinetics (lower values of $\tau$ ) in the mid-range RH $(30-50 \% \mathrm{RH})$ can be explained by the larger initial water content within the ionomer fibers, which lowers their density and the larger flux of water from the gas phase at high RH. This combination makes it easier for additional water molecules on the surface to diffuse into the ionomer fiber. When the $\mathrm{RH}$ is the highest (90\%), the fibers are nearly saturated and hence it is more difficult for additional water molecules to diffuse through the fiber, resulting therefore in higher $\tau$ values. 


\subsection{Anion Conductivity}

Figure 6 shows the bromide TP anion conductivity at $40{ }^{\circ} \mathrm{C}$ as a function of $\mathrm{RH}$ for ionomer fibers prepared at different $\mathrm{RH}_{\mathrm{ES}}$. As can be seen, $\mathrm{Br}^{-}$anion conductivity significantly increases with increasing RH. As can be seen, the anion conductivity of the electrospun ionomer mats made at lower $\mathrm{RH}_{\mathrm{ES}}$ are higher than mats electrospun at larger $\mathrm{RH}_{\mathrm{ES}}$. For instance, at $70 \% \mathrm{RH}$, the $\mathrm{Br}^{-} \mathrm{TP}$ anion conductivity of electrospun mat under $20 \% \mathrm{RH}_{\mathrm{ES}}$ is 6 times higher than that of a mat prepared at $40 \% \mathrm{RH}_{\mathrm{ES}}$.

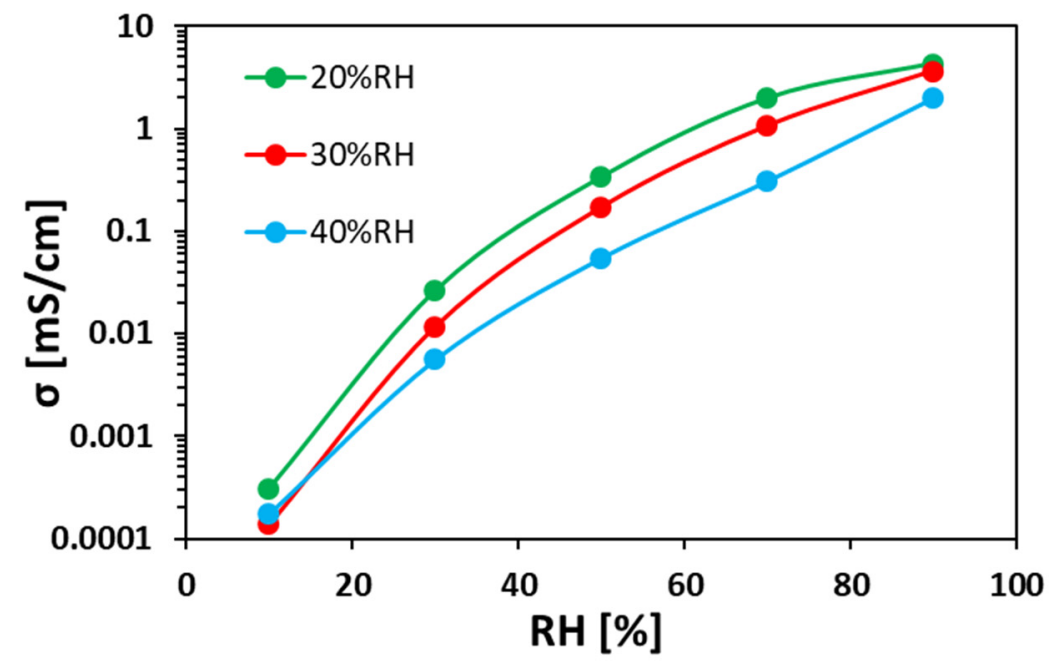

Figure 6. Bromide TP anion conductivity at $40{ }^{\circ} \mathrm{C}$ vs. $\mathrm{RH}$ for electrospun ionomer fibers prepared at different $\mathrm{RH}_{\mathrm{ES}}$.

A clear relation can be concluded from the results in Figures $5 \mathrm{a}$ and 6 . In both figures, the order is kept: the electrospun ionomer mat at $20 \% \mathrm{RH}_{\mathrm{ES}}$ has the highest $\mathrm{WU}$ and highest anion conductivity at RHs above $50 \%$, compared to both mats prepared at $30 \%$ and $40 \% \mathrm{RH}_{\mathrm{ES}}$. This indicates that higher WU and density promote faster ion transfer within the ionomer fibers and between them, which also explains the higher anion conductivity of the mat electrospun at $20 \% \mathrm{RH}_{\mathrm{ES}}$.

\section{Conclusions}

In this study, anion-conducting fiber mats were prepared by electrospinning (ES) at different relative humidity $\left(\mathrm{RH}_{\mathrm{ES}}\right)$ values. The ionomer nanofibers' morphology, anion conductivity, and water uptake (WU) were measured. Formation of branched thin fibers was observed in mats prepared at $\mathrm{RH}_{\mathrm{ES}} 20 \%$ and $30 \%$. The mechanism of branching as a function of $\mathrm{RH}_{\mathrm{ES}}$ in ES of anion-conducting material was discussed. It was shown that ionomer fiber diameter distribution is significantly affected by the $\mathrm{RH}_{\mathrm{ES}}$ up to $\mathrm{RH}=40 \%$. Above this value, the effect of $\mathrm{RH}_{\mathrm{ES}}$ on the fiber diameter distribution was marginal.

The results of WU and anion conductivity measurements showed that the ionomer mat electrospun under the lowest $\mathrm{RH}_{\mathrm{ES}}(20 \%)$ gained the highest $\mathrm{WU}(24 \%)$ and TP conductivity $\left(4.4 \mathrm{mS} \mathrm{cm}^{-1}\right)$ at $\mathrm{RH}=90 \%$. These results are associated with the large fibers' diameter and their high water capacity, which gives rise to higher anion conductivity.

The preparation of anion-conducting nanofibers prepared by ES process can be attractive for numerous applications including AEMFCs. Therefore, understanding the interplay between process conditions such as relative humidity during electrospinning and the nanofibers' structure, WU, as well as anion conductivity is important for the future design of these devices with tailored properties. This understanding is critical for effective water management within these future devices. 
Author Contributions: Data curation, O.E.; investigation, M.H. and M.M.-L.; methodology, V.B. and G.E.S.; supervision, M.M.-L., G.E.S., G.S.G., and D.R.D.; writing—original draft, M.H. and M.M.-L.; writing-review and editing, G.S.G. and D.R.D. All authors have read and agreed to the published version of the manuscript.

Acknowledgments: This work was partially funded by the Nancy \& Stephan Grand Technion Energy Program (GTEP); by the Ministry of Science, Technology \& Space of Israel through grant No. 3-12948; by the Israel Science Foundation (ISF) [grant No. 1481/17]; by the Russell Berrie Nanotechnology Institute, Technion; by the Ministry of National Infrastructure, Energy and Water Resources of Israel [grant No. 3-13671]. The authors would also like to acknowledge the financial support of Melvyn \& Carolyn Miller Fund for Innovation, as well as the support of Planning \& Budgeting Committee/ISRAEL Council for Higher Education (CHE) and Fuel Choice Initiative (Prime Minister Office of ISRAEL), within the framework of "Israel National Research Center for Electrochemical Propulsion (INREP)". GSG also acknowledges support from the Gruenbaum chair in Materials Engineering.

Conflicts of Interest: The authors declare no conflict of interest.

\section{References}

1. Chronakis, I.S. Novel nanocomposites and nanoceramics based on polymer nanofibers using electrospinning process-A review. J. Mater. Process. Technol. 2005, 167, 283-293. [CrossRef]

2. Teo, W.E.; Ramakrishna, S. A review on electrospinning design and nanofibre assemblies. Nanotechnology 2006, 17. [CrossRef] [PubMed]

3. Halperin, V.; Shter, G.E.; Beilin, V.; Grader, G.S. Mesoporous K/Fe-Al-O nanofibers by electrospinning of solution precursors. J. Mater. Res. 2015, 30, 3142-3150. [CrossRef]

4. Shmueli, Y.; Shter, G.E.; Assad, O.; Haick, H.; Sonntag, P.; Ricoux, P.; Grader, G.S. Structural and electrical properties of single $\mathrm{Ga} / \mathrm{ZnO}$ nanofibers synthesized by electrospinning. J. Mater. Res. 2012, 27, 1672-1679. [CrossRef]

5. Elishav, O.; Beilin, V.; Shter, G.E.; Dinner, O.; Halperin, V.; Grader, G.S. Formation of Core-Shell Mesoporous Ceramic Fibers. J. Am. Ceram. Soc. 2017, 100, 3370-3374. [CrossRef]

6. Cong, Y.; Liu, S.; Chen, H. Fabrication of conductive polypyrrole nanofibers by electrospinning. J. Nanomater. 2013, 2013, 1-7. [CrossRef]

7. Wang, Z.M. One-Dimensional Nanostructures; Springer Science \& Business Media: Berlin, Germany, 2008; Volume 3, ISBN 0387741321.

8. Baji, A.; Mai, Y.W.; Wong, S.C.; Abtahi, M.; Chen, P. Electrospinning of polymer nanofibers: Effects on oriented morphology, structures and tensile properties. Compos. Sci. Technol. 2010, 70, 703-718. [CrossRef]

9. Junoh, H.; Jaafar, J.; Norddin, M.N.A.M.; Ismail, A.F.; Othman, M.H.D.; Rahman, M.A.; Yusof, N.; Salleh, W.N.W.; Ilbeygi, H. A review on the fabrication of electrospun polymer electrolyte membrane for direct methanol fuel cell. J. Nanomater. 2015, 2015, 4. [CrossRef]

10. Cavaliere, S.; Subianto, S.; Savych, I.; Jones, D.J.; Rozière, J. Electrospinning: Designed architectures for energy conversion and storage devices. Energy Environ. Sci. 2011, 4, 4761. [CrossRef]

11. Megelski, S.; Stephens, J.S.; Chase, D.B.; Rabolt, J.F. Micro-and nanostructured surface morphology on electrospun polymer fibers. Macromolecules 2002, 35, 8456-8466. [CrossRef]

12. Casper, C.L.; Stephens, J.S.; Tassi, N.G.; Chase, D.B.; Rabolt, J.F. Controlling surface morphology of electrospun polystyrene fibers: Effect of humidity and molecular weight in the electrospinning process. Macromolecules 2004, 37, 573-578. [CrossRef]

13. Pisignano, D. Polymer Nanofibers: Building Blocks for Nanotechnology; Royal Society of Chemistry: London, UK, 2013; Volume 8, ISBN 1849735743.

14. Ramakrishna, S. An Introduction to Electrospinning and Nanofibers; WORLD SCIENTIFIC: Singapore, 2005; ISBN 978-981-256-415-3.

15. Haider, A.; Haider, S.; Kang, I.-K. A comprehensive review summarizing the effect of electrospinning parameters and potential applications of nanofibers in biomedical and biotechnology. Arab. J. Chem. 2018, 11, 1165-1188. [CrossRef]

16. Pham, Q.P.; Sharma, U.; Mikos, A.G. Electrospinning of polymeric nanofibers for tissue engineering applications: A review. Tissue Eng. 2006, 12, 1197-1211. [CrossRef] [PubMed]

17. Park, A.M.; Pintauro, P.N. Alkaline Fuel Cell Membranes from Electrospun Fiber Mats. Electrochem. Solid-State Lett. 2012, 15, B27. [CrossRef] 
18. Bajon, R.; Balaji, S.; Guo, S.M. Electrospun Nafion Nanofiber for Proton Exchange Membrane Fuel Cell Application. J. Fuel Cell Sci. Technol. 2009, 6, 031004. [CrossRef]

19. Sundarrajan, S.; Ramakrishna, S. Green Processing of a Cationic Polyelectrolyte Nanofibers in the Presence of Poly (vinyl alcohol). Int. J. Green Nanotechnol. 2011, 3, 244-249. [CrossRef]

20. Sridhar, R.; Sundarrajan, S.; Vanangamudi, A.; Singh, G.; Matsuura, T.; Ramakrishna, S. Green processing mediated novel polyelectrolyte nanofibers and their antimicrobial evaluation. Macromol. Mater. Eng. 2014, 299, 283-289. [CrossRef]

21. Sun, J.; Bubel, K.; Chen, F.; Kissel, T.; Agarwal, S.; Greiner, A. Nanofibers by green electrospinning of aqueous suspensions of biodegradable block copolyesters for applications in medicine, pharmacy and agriculture. Macromol. Rapid Commun. 2010, 31, 2077-2083. [CrossRef]

22. Huang, L.; Bui, N.; Manickam, S.S.; McCutcheon, J.R. Controlling electrospun nanofiber morphology and mechanical properties using humidity. J. Polym. Sci. Part B Polym. Phys. 2011, 49, 1734-1744. [CrossRef]

23. Nezarati, R.M.; Eifert, M.B.; Cosgriff-Hernandez, E. Effects of humidity and solution viscosity on electrospun fiber morphology. Tissue Eng. Part C Methods 2013, 19, 810-819. [CrossRef]

24. Zheng, J.; Zhang, H.; Zhao, Z.; Han, C.C. Construction of hierarchical structures by electrospinning or electrospraying. Polymer 2012, 53, 546-554. [CrossRef]

25. Park, J.-Y.; Lee, I.-H. Relative humidity effect on the preparation of porous electrospun polystyrene fibers. J. Nanosci. Nanotechnol. 2010, 10, 3473-3477. [CrossRef] [PubMed]

26. Kim, G.-T.; Lee, J.-S.; Shin, J.-H.; Ahn, Y.-C.; Hwang, Y.-J.; Shin, H.-S.; Lee, J.-K.; Sung, C.-M. Investigation of pore formation for polystyrene electrospun fiber: Effect of relative humidity. Korean J. Chem. Eng. 2005, 22, 783-788. [CrossRef]

27. Pai, C.-L.; Boyce, M.C.; Rutledge, G.C. Morphology of porous and wrinkled fibers of polystyrene electrospun from dimethylformamide. Macromolecules 2009, 42, 2102-2114. [CrossRef]

28. Ono, H.; Miyake, J.; Shimada, S.; Uchida, M.; Miyatake, K. Anion exchange membranes composed of perfluoroalkylene chains and ammonium-functionalized oligophenylenes. J. Mater. Chem. A 2015, 3, 21779-21788. [CrossRef]

29. Melo, L.D.; Mamizuka, E.M.; Carmona-Ribeiro, A.M. Antimicrobial particles from cationic lipid and polyelectrolytes. Langmuir 2010, 26, 12300-12306. [CrossRef]

30. Huang, T.; He, G.; Xue, J.; Otoo, O.; He, X.; Jiang, H.; Zhang, J.; Yin, Y.; Jiang, Z.; Douglin, J.C. Self-crosslinked blend alkaline anion exchange membranes with bi-continuous phase separated morphology to enhance ion conductivity. J. Memb. Sci. 2020, 597, 117769. [CrossRef]

31. Siroma, Z.; Ioroi, T.; Fujiwara, N.; Yasuda, K. Proton conductivity along interface in thin cast film of Nafion ${ }^{\circledR}$. Electrochem. Commun. 2002, 4, 143-145. [CrossRef]

32. Willdorf-Cohen, S.; Mondal, A.N.; Dekel, D.R.; Diesendruck, C.E. Chemical stability of poly (phenylene oxide)-based ionomers in an anion exchange-membrane fuel cell environment. J. Mater. Chem. A 2018, 6, 22234-22239. [CrossRef]

33. Karan, K. Interesting Facets of Surface, Interfacial, and Bulk Characteristics of Perfluorinated Ionomer Films. Langmuir 2019, 35, 13489-13520. [CrossRef]

34. Amel, A.; Gavish, N.; Zhu, L.; Dekel, D.R.; Hickner, M.A.; Ein-Eli, Y. Bicarbonate and chloride anion transport in anion exchange membranes. J. Memb. Sci. 2016, 514, 125-134. [CrossRef]

35. Maurya, S.; Shin, S.-H.; Kim, Y.; Moon, S.-H. A review on recent developments of anion exchange membranes for fuel cells and redox flow batteries. RSC Adv. 2015, 5, 37206-37230. [CrossRef]

36. Merle, G.; Wessling, M.; Nijmeijer, K. Anion exchange membranes for alkaline fuel cells: A review. J. Memb. Sci. 2011, 377, 1-35. [CrossRef]

37. Amel, A.; Smedley, S.B.; Dekel, D.R.; Hickner, M.A.; Ein-Eli, Y. Characterization and chemical stability of anion exchange membranes cross-linked with polar electron-donating linkers. J. Electrochem. Soc. 2015, 162, F1047-F1055. [CrossRef]

38. Park, J.; Wycisk, R.; Pintauro, P.; Yarlagadda, V.; Van Nguyen, T. Electrospun Nafion ${ }^{\circledR} /$ Polyphenylsulfone composite membranes for regenerative Hydrogen bromine fuel cells. Materials. 2016, 9, 143. [CrossRef]

39. Choi, J.; Lee, K.M.; Wycisk, R.; Pintauro, P.N.; Mather, P.T. Nanofiber composite membranes with low equivalent weight perfluorosulfonic acid polymers. J. Mater. Chem. 2010, 20, 6282. [CrossRef]

40. Ballengee, J.B.; Pintauro, P.N. Preparation of nanofiber composite proton-exchange membranes from dual fiber electrospun mats. J. Memb. Sci. 2013, 442, 187-195. [CrossRef] 
41. Sood, R.; Cavaliere, S.; Jones, D.J.; Rozière, J. Electrospun nanofibre composite polymer electrolyte fuel cell and electrolysis membranes. Nano Energy 2016, 26, 729-745. [CrossRef]

42. Subianto, S.; Giancola, S.; Ercolano, G.; Nabil, Y.; Jones, D.; Rozière, J.; Cavaliere, S. Electrospun nanofibers for low-temperature proton exchange membrane fuel cells. In Electrospinning for Advanced Energy and Environmental Applications; Sara, C., Ed.; CRC Press: Boca Raton, FL, USA, 2015; pp. 29-59. ISBN 1482217678.

43. Subianto, S.; Cavaliere, S.; Jones, D.J.; Rozière, J. Effect of side-chain length on the electrospinning of perfluorosulfonic acid ionomers. J. Polym. Sci. Part A Polym. Chem. 2013, 51, 118-128. [CrossRef]

44. Park, A.M.; Turley, F.E.; Wycisk, R.J.; Pintauro, P.N. Electrospun and Cross-Linked Nano fiber Composite Anion Exchange Membranes. Macromolecules 2014, 47, 227-235. [CrossRef]

45. Park, A.M.; Wycisk, R.J.; Ren, X.; Turley, F.E.; Pintauro, P.N. Crosslinked poly(phenylene oxide)-based nanofiber composite membranes for alkaline fuel cells. J. Mater. Chem. A 2016, 4, 132-141. [CrossRef]

46. Yarin, A.L.; Kataphinan, W.; Reneker, D.H. Branching in electrospinning of nanofibers. J. Appl. Phys. 2005, 98, 64501. [CrossRef]

47. Tan, S.; Huang, X.; Wu, B. Some fascinating phenomena in electrospinning processes and applications of electrospun nanofibers. Polym. Int. 2007, 56, 1330-1339. [CrossRef]

48. Reneker, D.H.; Yarin, A.L. Electrospinning jets and polymer nanofibers. Polymer 2008, 49, $2387-2425$. [CrossRef]

49. Gevorkyan, A.; Shter, G.E.; Shmueli, Y.; Buk, A.; Meir, R.; Grader, G.S. Branching effect and morphology control in electrospun PbZr 0.52 Ti 0.48 O 3 nanofibers. J. Mater. Res. 2014, 29, 1721-1729. [CrossRef]

50. Gottesfeld, S.; Dekel, D.R.; Page, M.; Bae, C.; Yan, Y.; Zelenay, P.; Kim, Y.S. Anion exchange membrane fuel cells: Current status and remaining challenges. J. Power Sources 2018, 375, 170-184. [CrossRef]

51. Dekel, D.R.; Rasin, I.G.; Brandon, S. Predicting performance stability in anion exchange membrane fuel cells. J. Power Sources 2019, 420, 118-123. [CrossRef]

52. Omasta, T.J.; Park, A.M.; LaManna, J.M.; Zhang, Y.; Peng, X.; Wang, L.; Jacobson, D.L.; Varcoe, J.R.; Hussey, D.S.; Pivovar, B.S. Beyond catalysis and membranes: Visualizing and solving the challenge of electrode water accumulation and flooding in AEMFCs. Energy Environ. Sci. 2018, 11, 551-558. [CrossRef]

53. Miller, H.A.; Lavacchi, A.; Vizza, F.; Marelli, M.; Di Benedetto, F.; D’Acapito, F.; Paska, Y.; Page, M.; Dekel, D.R. $\mathrm{A} \mathrm{Pd} / \mathrm{C}-\mathrm{CeO}_{2}$ Anode Catalyst for High-Performance Platinum-Free Anion Exchange Membrane Fuel Cells. Angew. Chem. 2016, 128, 6108-6111. [CrossRef]

54. Dekel, D.R. Alkaline membrane fuel cell (AMFC) materials and system improvement-state-of-the-art. ECS Trans. 2013, 50, 2051-2052. [CrossRef]

55. Zheng, Y.; Ash, U.; Pandey, R.P.; Ozioko, A.G.; Ponce-González, J.; Handl, M.; Weissbach, T.; Varcoe, J.R.; Holdcroft, S.; Liberatore, M.W.; et al. Water Uptake Study of Anion Exchange Membranes. Macromolecules 2018, 51, 3264-3278. [CrossRef]

56. Noga, Z.; Mondal, A.N.; Weissbach, T.; Steven, H.; Dekel, D.R. Effect of CO2 on the properties of anion exchange membranes for fuel cell applications. J. Member. Sci. 2019, 586, 140-150.

57. Ziv, N.; Mustain, W.E.; Dekel, D.R. The Effect of Ambient Carbon Dioxide on Anion-Exchange Membrane Fuel Cells. ChemSusChem 2018, 11, 1136-1150. [CrossRef] [PubMed]

58. Zhegur, A.; Gjineci, N.; Willdorf-Cohen, S.; Mondal, A.N.; Diesendruck, C.E.; Gavish, N.; Dekel, D.R. Changes of Anion Exchange Membrane Properties During Chemical Degradation. ACS Appl. Polym. Mater. 2020, 2, 360-367. [CrossRef]

59. Li, Y.S.; Zhao, T.S.; Yang, W.W. Measurements of water uptake and transport properties in anion-exchange membranes. Int. J. Hydrog. Energy 2010, 35, 5656-5665. [CrossRef]

60. Kusoglu, A.; Kwong, A.; Clark, K.T.; Gunterman, H.P.; Weber, A.Z. Water Uptake of Fuel-Cell Catalyst Layers. J. Electrochem. Soc. 2012, 159, F530-F535. [CrossRef]

61. Ziv, N.; Dekel, D.R. A practical method for measuring the true hydroxide conductivity of anion exchange membranes. Electrochem. Commun. 2018, 88, 109-113. [CrossRef]

62. Cooper, K. Characterizing through-plane and in-plane ionic conductivity of polymer electrolyte membranes. ECS Trans. 2011, 41, 1371-1380.

63. Ding, C.; Fang, H.; Duan, G.; Zou, Y.; Chen, S.; Hou, H. Investigating the draw ratio and velocity of an electrically charged liquid jet during electrospinning. RSC Adv. 2019, 9, 13608-13613. [CrossRef]

64. Mann-Lahav, M.; Halabi, M.; Shter, G.E.; Beilin, V.; Balaish, M.; Ein-Eli, Y.; Dekel, D.R.; Grader, G.S. Electrospun ionomeric fibers with anion conducting properties. Adv. Funct. Mater. 2019, 1901733. [CrossRef] 
65. Elishav, O.; Grader, G.S. Electrospun Fe-Al-O Nanobelts for Selective $\mathrm{CO}_{2}$ Hydrogenation to Light Olefins. Unpublished work. 2020.

66. De Vrieze, S.; Van Camp, T.; Nelvig, A.; Hagström, B.; Westbroek, P.; De Clerck, K. The effect of temperature and humidity on electrospinning. J. Mater. Sci. 2009, 44, 1357. [CrossRef]

67. Pelipenko, J.; Kristl, J.; Janković, B.; Baumgartner, S.; Kocbek, P. The impact of relative humidity during electrospinning on the morphology and mechanical properties of nanofibers. Int. J. Pharm. 2013, 456, 125-134. [CrossRef] [PubMed]

68. Baumgarten, P.K. Electrostatic spinning of acrylic microfibers. J. Colloid Interface Sci. 1971, 36, 71-79. [CrossRef]

(C) 2020 by the authors. Licensee MDPI, Basel, Switzerland. This article is an open access article distributed under the terms and conditions of the Creative Commons Attribution (CC BY) license (http://creativecommons.org/licenses/by/4.0/). 